\title{
The Impact of Insurance Company's Profitability on the Economic Growth
}

\author{
Siti Nurain Muhmad, Wesam Salameh Alzboon, Fatima Alhamshary
}

\begin{abstract}
This paper investigates the impact of Jordanian insurance company's profitability on the economic growth during the period 2007-2016. Regression analysis using random effect model was adopted after applying Hausman test. The results reveals that earning per share, and net realized premiums to shareholders equity have a negative impact on the economic growth, also a significant positive impact for the return on equity on the economic growth has been founded. According to the results the study recommended to encourage individuals and investors to participate in insurance in various fields.
\end{abstract}

Index Terms: insurance company, profitability, economic growth, Amman stock exchange.

\section{INTRODUCTION}

The financial institutions in the economy as well as insurance companies determined their role as a channel funds and transfers risks from one economic unit to another economic units in order to facilitate trade and resources arrangement. Where, the efficient and effective financial system shows through savings mobilization, risk transfer and intermediation (Sambasivam \& Ayele, 2013).

Consequently, insurance companies contribute to the economic growth and development of every economy through provide unique financial services, and to achieve the sustainable in the competitive globalized environment; insurance companies must take into consideration their performance in earning profit as a pre requisite, so, it can attract outside capital and meet their objectives. (Berhe \& Kaur, 2017)

Mehari \& Aemiro, (2013), illustrate that the performance of any business firm not limited to the increase the market value of that specific firm, it also leads towards the growth of the whole sector that the firm related, which ultimately leads towards the overall prosperity of the economy.

On the other hand, Naveed, Zulfqar, \& Ahmad, (2011) illustrate that the efficiency of financial intermediaries and risk transfer, may has negative effect on the economic growth, while at the same time the lack of the solvability lead to systemic crisis, which bring adverse consequences for the whole economy.

\section{Revised Manuscript Received on September 22, 2019}

Dr.*Siti Nurain Muhmad, PhD Bachelor of Accounting Programme, School of Maritime Business and Management, University Malaysia Terengganu, 21030 Kuala Nerus, Terengganu, Malaysia. Email: sitinurain@umt.edu.my

Wesam Salameh Alzboon, PhD Student, University Malaysia Terengganu, Terengganu, Malaysia. Email: wesamezboon@ @otmail.com.

Fatima Alhamshary, Lecturer, Administration \& Financial Sciences Department, Community Collage of Qatif, Imam Abdulrahman Bin Faisal University, P.O. Box 36675, Dammam, Saudi Arabia. Email: falhamshary@iau.edu.sa.
In this study we will examine the impact of insurance company's profitability on the economic growth in the Hashemite Kingdom of Jordan.

\section{PROBLEM OF THE STUDY}

Several studies have shown the importance of the financial sector in driving the economic growth of the country; there are many studies that have examined the insurance sector and its relation to economic growth. However this relationship is still characterized by ambiguity and lack of clarity in the State of Jordan, as within the knowledge of the researcher there are no studies dealt with this relationship and applied in the Jordanian insurance market. Accordingly, the problem of study is determined in Lack of knowledge about the impact of the profitability of insurance companies on the economic growth in Jordan, despite the importance of these companies and the importance of pursuing their role in economic growth.

We can formulate the problem of the study through the following questions:

\section{A. Main question}

To what extent does profitability in the insurance industry generate an effect on economic growth in Jordan?

\section{B. Sub questions}

1. To what extent does earning per share in the insurance industry generate an effect on economic growth in Jordan?

2. To what extent does net realized premiums to shareholders equity in the insurance industry generate an effect on economic growth in Jordan?

3. To what extent do net technical reserves to net realized premiums in the insurance industry generate an effect on economic growth in Jordan?

4. To what extent does return on equity in the insurance industry generate an effect on economic growth in Jordan?

\section{OBJECTIVES OF THE STUDY}

The main objective of this study is to determine the effect of profitability in the insurance industry on economic growth in Jordan. Specifically, this study tries to achieve the following objectives:

1. To determine the relationship between earning per share in insurance company and economic growth in Jordan.

2. To determine the relationship between net realized premiums to shareholders equity in insurance company and economic growth in Jordan.

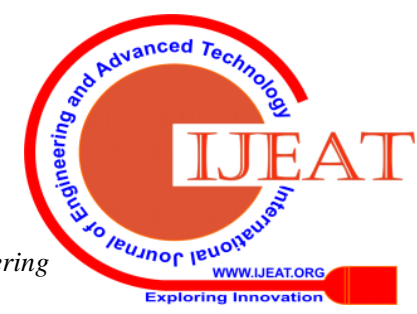


3. To determine the relationship between net technical reserves to net realized premiums in insurance company and economic growth in Jordan.

4. To determine the relationship between return on equity in insurance company and economic growth in Jordan.

\section{IMPORTANCE OF THE STUDY}

Economic growth is considered as the main determinant for the development of the economic situation of the society, which contributes to the welfare of society and the standard of living of individuals.

The insurance sector has recently played a prominent role in the provision of insurance services to various individuals and through different types depending on developments in the needs of the beneficiaries.

Therefore, it is necessary to identify the role of the insurance sector in the state economy by studying the impact of this sector's profitability on economic growth; to determine the extent of its contribution to the economy, and therefore to reach suggestions and recommendations that help to develop it and thus develop the economic situation.

\section{REVIEW OF RELATED LITERATURE}

Alomari \& Azzam (2017) study the effect of the micro and macro factors on the performance of the listed Jordanian insurance companies during the period (2008-2014). The sample of the study consisted of 24 insurance companies listed in Amman stock exchange (ASE), where a multiple regression model has been built and analyzed the data through using ordinary least square (OLS) and applying random effect.

The results indicated that there is a negative and a significant effect for the liquidity, leverage and under writing risks on the profitability of the listed Jordanian insurance companies, while it was found a statically, positive and a significant effect for size of the company, market share and GDP on the profitability, on the other hand the inflation has no significant.

Berhe \& Kaur (2017), aimed to examined the determinants of insurance companies' profitability in Ethiopia during the period (2005-2014). The sample of the study consisted of 17 insurance companies, where a multiple regression model has been built and analyzed the data through using ordinary least square (OLS). The results revealed a positive and significant correlation ship between the Gross Domestic Product (GDP) and profitability of Ethiopian insurers. Beside that it was found that the main factors that significantly affect the profitability of insurance companies were size of insurance, capital adequacy, liquidity ratio and growth rate of GDP. While leverage ratio, loss ratio, market share and inflation rate had no significant effect on insurance companies profitability.

Lire \& Tegegn (2016), discussed the determinants of profitability in private insurance companies in Ethiopia during the period (2005-2015). The sample of the study consisted of 8 private insurance companies, where a multiple regression model has been built and analyzed the data through using ordinary least square (OLS) and fixed effect approach of panel data. The results indicated a positive, statistical and significant effect for the underwriting risk negatively, company size on the private insurers' profitability, while; premium growth and solvency ratio have negative effect. On the other hand it was found that the economic growth rate has significant effect on the profitability of private insurance companies in Ethiopia, on the contrary of inflation and interest rate which had no effect.

Ortyński (2016), aimed to know the determinants of profitability of general insurance companies performance in Poland during the period (2006-2013). To achieve the goal of the study a weight least square (WLS) method and intergroup method with the use of the GRETL program were used to analyze the data. The results showed a statistically significant positive influence for the size of a company and the economic growth on the profitability of insurance companies in Poland.

Datu (2016) studied the effect of Insurer-specific indicators and macroeconomics on the profitability in Philippine non-life insurance market during the period of (2008 -2012). The sample of the study consisted of 69 non-life insurance companies, where a multiple regression model has been built and analyzed the data through using ordinary least square (OLS) and fixed effect approach of panel data. The empirical results showed that there is no effect for both economic growth and inflation on the profitability, while it was found that underwriting risk, reinsurance utilization, firm size, financial leverage and input cost have significant effect on the profitability in Philippine non-life insurance market.

Adekola (2016), studied the effect of banks profitability on economic growth in Nigeria during the period (2005-2014). The sample of the study consists of five Nigerian banks which were chosen in a random method. The regression analysis has been adopted for the study with a pooled OLS (POLS) equation. The study revealed that profitability of banks through Return on capital employed (ROCE) and Return on equity (ROE) has a negative significant effect on economic growth in Nigeria.

Eliskovska (2015) aimed to investigate the impact of the most representative microeconomic and macroeconomic determinants on the profitability of the insurance sector in Macedonia during the period of (2006 to 2011). To achieve the goal of the study, quarterly data has been collected and analyzed by using Johansen cointegration technique. The empirical results indicated a positive and statistical impact for assets on the profitability of the insurance sector in Macedonia, beside that the results showed a statistically significant negative impact for the economic growth on the profitability.

Gabriel (2015) examined the impact of insurance sector development on the growth of Nigeria economy during the period (1981-2013). To achieve the goal of the study it was depend on quasi experimental research design, and the data was collected from the CBN statistical bulletin and annual report. The result revealed that there is a long run equilibrium association between insurance sector development and economic growth. The results also showed a positive and significant relationship between the total insurance investment and insurance 
premium and between the economic growth.

Lee (2014) investigated the impact of firm specific factors and macroeconomics on profitability in Taiwanese property-liability insurance industry during the period (1999-2009). The sample of the study consisted from 15 P-L insurers, where; it's data has been collected and analyzed through applying ordinary least square (OLS) regression model, fixed effect model (FEM) and random effect model (REM). The results found a significant impact for underwriting risk, reinsurance usage, input cost, return on investment (ROI) and financial holding group on the profitability. In addition, it was found that economic growth rate has positive significant impact on profitability in Taiwanese property-liability insurance industry.

Njegomir \& Stojić (2010) investigated the impact of insurance on economic growth in ex- Yugoslavia region which formerly were constituent republics of Socialist Federal Republic of Yugoslavia, and the study depend on fixed effects models in analyzing the data. The empirical results found a positive impact for the insurance company on the economic growth on Yugoslavia.

Haiss \& Sümegi (2008) studied the impact of both insurance investment and premiums on economic growth in Europe during the period (1992-2005). The sample of the study consists of 29 European countries. The regression analysis has been adopted for the study with a pooled OLS (POLS) equation. The results revealed the existing of positive relationship between life insurance and interest rate and between economic growth.

\section{STUDY HYPOTHESIS}

\section{A. Main Hypothesis}

Ha: There is a significant statistical effect for profitability in insurance company on economic growth in Jordan.

\section{B. Sub Hypotheses}

Ha1: There is a significant statistical effect for earning per share in insurance company on economic growth in Jordan.

$\mathrm{Ha} 2$ : There is a significant statistical effect for net realized premiums to shareholders equity in insurance company on economic growth in Jordan.

Ha3: There is a significant statistical effect for net technical reserves to net realized premiums in insurance company on economic growth in Jordan.

Ha4: There is a significant statistical effect for return on equity in insurance company on economic growth in Jordan.

\section{THEORETICAL FRAMEWORK}

\section{A. Insurance Sector in Jordan}

The number of insurance companies existing in Jordan market as a member in Jordan Insurance Federation (JIF) has reached (24) companies in 2017. The capital of these companies amounted to (267.65) million dinars. These companies practice motor insurance, marine insurance, fire risk, general accidents risk, credit insurance, life insurance and medical insurance. during the period (2004-2008). The data covered 5 countries,

There is no such companies in Jordanian market specialized in re-insurance business.

The table below illustrates the insurance companies existing in Jordan's insurance market in 2017 each according to its specialty:

Table (1): The insurance companies existing in Jordan's insurance market in 2017 each according to its specialty

\begin{tabular}{|c|c|c|c|c|c|}
$\begin{array}{c}\text { General } \\
\text { Insuranc } \\
\text { e }\end{array}$ & $\begin{array}{c}\text { Life \& } \\
\text { General } \\
\text { Insurance } \\
\text { Companies } \\
\begin{array}{c}\text { Compan } \\
\text { ies } \\
\text { Medical }\end{array}\end{array}$ & $\begin{array}{c}\text { Life Addition } \\
\text { Insura } \\
\text { nce } \\
\text { to Medical } \\
\text { Ins. }\end{array}$ & $\begin{array}{c}\text { Gemparal } \\
\text { nies } \\
\text { Insuran } \\
\text { ce } \\
\text { Compa } \\
\text { nies } \\
\text { Only }\end{array}$ & $\begin{array}{c}\text { Re-Insu } \\
\text { rance } \\
\text { Compa } \\
\text { nies }\end{array}$ & $\begin{array}{c}\text { Tot } \\
\text { al }\end{array}$ \\
\hline 7 & 15 & 1 & 1 & Nil & 24 \\
\hline
\end{tabular}

The table below illustrates the percentage change in gross premiums and total paid claims in Jordanian insurance sector during the period (2004-2015). We can note that gross premiums and total paid claims have been decreased by the end of 2015 to be $(4.7 \%)$ and $(-0.3 \%)$ respectively compare with the year 2004.

Table (2): the percentage change in gross premiums and total paid claims in Jordanian insurance sector

\begin{tabular}{|c|c|c|}
\hline Year & Premiums Change\% & Paid Claims Change\% \\
\hline 2004 & $11,6 \%$ & $14,3 \%$ \\
\hline 2005 & $14,5 \%$ & $15,6 \%$ \\
\hline 2006 & $17,7 \%$ & $22 \%$ \\
\hline 2007 & $12,7 \%$ & $19 \%$ \\
\hline 2008 & $14,3 \%$ & $5,5 \%$ \\
\hline 2009 & $9,6 \%$ & $18,8 \%$ \\
\hline 2010 & $11,9 \%$ & $7,1 \%$ \\
\hline 2011 & $6,9 \%$ & $22,4 \%$ \\
\hline 2012 & $6,7 \%$ & $-2,8 \%$ \\
\hline 2013 & $6,3 \%$ & $-1,9 \%$ \\
\hline 2014 & $7,1 \%$ & $17,6 \%$ \\
\hline 2015 & $4,7 \%$ & $-0,3 \%$ \\
\hline$S 0 u r$ & $50 r(12 \%)$ & \\
\hline
\end{tabular}

Source: Jordan insurance federation (JOIF)

The table below illustrates the growth of premiums for all insurance classes during the period $(2010$ - 2015) in Jordanian dinar. We can note that the growth of premiums for marine $\&$ aviation insurance and general accident insurance has been decrease in 2015 compare with the year 2014, while the growth of other classes has been increased.

Table (3): Growth of premiums for all insurance classes (JD)

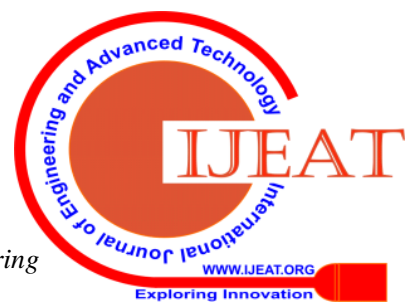




\begin{tabular}{|c|c|c|c|c|c|c|}
\hline & 2010 & 2011 & 2012 & 2013 & 2014 & 2015 \\
\hline $\begin{array}{l}\text { MARINE \& } \\
\text { AVIATION } \\
\text { INSURANCE }\end{array}$ & $\begin{array}{l}24,61 \\
3,910 \\
\end{array}$ & $\begin{array}{l}30,73 \\
8,029\end{array}$ & $\begin{array}{l}30,15 \\
0,137\end{array}$ & $\begin{array}{l}28,08 \\
6,631\end{array}$ & $\begin{array}{l}28,65 \\
8,379\end{array}$ & $\begin{array}{l}24,08 \\
5,474\end{array}$ \\
\hline $\begin{array}{l}\text { FIRE } \\
\text { INSURANCE }\end{array}$ & $\begin{array}{l}56,34 \\
2,885\end{array}$ & $\begin{array}{l}57,36 \\
9,056\end{array}$ & $\begin{array}{l}60,65 \\
1,004\end{array}$ & $\begin{array}{l}68,33 \\
9,553\end{array}$ & $\begin{array}{l}69,11 \\
9,571\end{array}$ & $\begin{array}{l}69,51 \\
0,772\end{array}$ \\
\hline $\begin{array}{l}\text { MOTOR } \\
\text { INSURANCE }\end{array}$ & $\begin{array}{c}176,7 \\
14,73 \\
9\end{array}$ & $\begin{array}{c}184,6 \\
88,00 \\
9\end{array}$ & $\begin{array}{c}193,3 \\
32,01 \\
8\end{array}$ & $\begin{array}{c}201,6 \\
72,15 \\
2\end{array}$ & $\begin{array}{c}212,5 \\
29,08 \\
1\end{array}$ & $\begin{array}{c}221,8 \\
82,43 \\
5\end{array}$ \\
\hline $\begin{array}{l}\text { GENERAL } \\
\text { ACCIDENT } \\
\text { INSURANCE }\end{array}$ & $\begin{array}{l}18,41 \\
4,831\end{array}$ & $\begin{array}{l}17,43 \\
2,140\end{array}$ & $\begin{array}{l}15,95 \\
3,296\end{array}$ & $\begin{array}{l}17,64 \\
8,639\end{array}$ & $\begin{array}{l}19,93 \\
5,818\end{array}$ & $\begin{array}{l}18,47 \\
4,171\end{array}$ \\
\hline $\begin{array}{l}\text { CREDIT } \\
\text { INSURANCE }\end{array}$ & $\begin{array}{c}464,0 \\
35\end{array}$ & $\begin{array}{c}455,0 \\
09\end{array}$ & $\begin{array}{c}307,1 \\
60\end{array}$ & $\begin{array}{c}397,9 \\
79\end{array}$ & $\begin{array}{c}699,0 \\
52\end{array}$ & $\begin{array}{c}979,9 \\
69\end{array}$ \\
\hline $\begin{array}{l}\text { TOTAL } \\
\text { NON-LIFE } \\
\text { INSURANCE } \\
\text { S }\end{array}$ & $\begin{array}{c}276,5 \\
50,40 \\
0\end{array}$ & $\begin{array}{c}290,6 \\
82,24 \\
3\end{array}$ & $\begin{array}{c}300,3 \\
93,61 \\
5\end{array}$ & $\begin{array}{c}316,1 \\
44,95 \\
4\end{array}$ & $\begin{array}{c}330,9 \\
41,90 \\
1\end{array}$ & $\begin{array}{c}334,9 \\
32,82 \\
1\end{array}$ \\
\hline $\begin{array}{l}\text { LIFE } \\
\text { ASSURANC } \\
\text { E }\end{array}$ & $\begin{array}{l}38,03 \\
8,112\end{array}$ & $\begin{array}{l}40,80 \\
0,332\end{array}$ & $\begin{array}{l}43,76 \\
6,880\end{array}$ & $\begin{array}{l}47,43 \\
7,142\end{array}$ & $\begin{array}{l}53,09 \\
6,513\end{array}$ & $\begin{array}{l}61,03 \\
8,255\end{array}$ \\
\hline $\begin{array}{l}\text { MEDICAL } \\
\text { INSURANCE }\end{array}$ & $\begin{array}{l}94,02 \\
6,914\end{array}$ & $\begin{array}{c}105,9 \\
48,17 \\
1\end{array}$ & $\begin{array}{c}117,5 \\
06,16 \\
0\end{array}$ & $\begin{array}{c}127,3 \\
49,80 \\
9\end{array}$ & $\begin{array}{c}141,6 \\
69,76 \\
1\end{array}$ & $\begin{array}{c}154,3 \\
95,79 \\
4\end{array}$ \\
\hline $\begin{array}{l}\text { TOTAL } \\
\text { UNDERWRI } \\
\text { TTEN } \\
\text { PREMIUMS }\end{array}$ & $\begin{array}{c}408,6 \\
15,42 \\
6\end{array}$ & $\begin{array}{c}437,4 \\
30,74 \\
6\end{array}$ & $\begin{array}{c}461,6 \\
66,65 \\
5\end{array}$ & $\begin{array}{c}490,9 \\
31,90 \\
5\end{array}$ & $\begin{array}{c}525,7 \\
08,17 \\
5\end{array}$ & $\begin{array}{c}550,3 \\
66,87 \\
0\end{array}$ \\
\hline
\end{tabular}

Source: Jordan insurance federation (JOIF)

The table below illustrates the growth of paid claims for all insurance classes during the period (2010 - 2015) in Jordanian dinar. We can note that the growth of paid claims for fire insurance, general accident insurance, total non-life insurances and life insurance has been decrease in 2015 compare with the year 2014, while the growth of other classes has been increased.

Table (4): Growth of paid claims for all insurance classes (JD)

\begin{tabular}{|c|c|c|c|c|c|c|}
\hline & 2010 & 2011 & 2012 & 2013 & 2014 & 2015 \\
\hline $\begin{array}{l}\text { MARINE \& } \\
\text { AVIATION } \\
\text { INSURANC } \\
\text { E }\end{array}$ & $\begin{array}{c}4,684, \\
069\end{array}$ & $\begin{array}{c}5,003, \\
089\end{array}$ & $\begin{array}{l}11,80 \\
9,620\end{array}$ & $\begin{array}{c}6,411, \\
414\end{array}$ & $\begin{array}{c}7,074, \\
415\end{array}$ & $\begin{array}{c}7,309 \\
789\end{array}$ \\
\hline $\begin{array}{l}\text { FIRE } \\
\text { INSURANC } \\
\text { E }\end{array}$ & $\begin{array}{l}11,23 \\
4,683\end{array}$ & $\begin{array}{l}25,56 \\
9,297\end{array}$ & $\begin{array}{l}12,53 \\
4,898\end{array}$ & $\begin{array}{l}12,75 \\
0,863\end{array}$ & $\begin{array}{l}42,14 \\
2,301\end{array}$ & $\begin{array}{l}19,91 \\
9,195\end{array}$ \\
\hline $\begin{array}{l}\text { MOTOR } \\
\text { INSURANC }\end{array}$ & $\begin{array}{l}160,3 \\
31,45\end{array}$ & $\begin{array}{l}190,7 \\
83,41\end{array}$ & $\begin{array}{l}171,6 \\
99,12\end{array}$ & $\begin{array}{l}160,3 \\
88,03\end{array}$ & $\begin{array}{l}175,6 \\
78,59\end{array}$ & $\begin{array}{l}188,4 \\
62,27\end{array}$ \\
\hline $\mathbf{E}$ & 9 & 0 & 5 & 2 & 2 & 0 \\
\hline
\end{tabular}

\begin{tabular}{|c|c|c|c|c|c|c|}
\hline $\begin{array}{l}\text { GENERAL } \\
\text { ACCIDENT } \\
\text { INSURANC } \\
\text { E }\end{array}$ & $\begin{array}{c}2,658 \\
052\end{array}$ & $\begin{array}{c}2,938 \\
564\end{array}$ & $\begin{array}{c}2,165 \\
157\end{array}$ & $\begin{array}{c}1,827, \\
511\end{array}$ & $\begin{array}{c}5,405, \\
758\end{array}$ & $\begin{array}{c}3,928 \\
970\end{array}$ \\
\hline $\begin{array}{l}\text { CREDIT } \\
\text { INSURANC } \\
\text { E }\end{array}$ & $\begin{array}{c}2,093 \\
502\end{array}$ & $\begin{array}{c}911,1 \\
12\end{array}$ & $\begin{array}{c}838,4 \\
58\end{array}$ & $\begin{array}{c}803,0 \\
72\end{array}$ & $\begin{array}{c}717,1 \\
24\end{array}$ & $\begin{array}{c}906,7 \\
72\end{array}$ \\
\hline $\begin{array}{l}\text { TOTAL } \\
\text { NON-LIFE } \\
\text { INSURANC } \\
\text { ES }\end{array}$ & $\begin{array}{c}181,0 \\
01,76 \\
5\end{array}$ & $\begin{array}{l}225,2 \\
05,47 \\
2\end{array}$ & $\begin{array}{c}199,0 \\
47,25 \\
8\end{array}$ & $\begin{array}{c}182,1 \\
80,89 \\
2\end{array}$ & $\begin{array}{c}231,0 \\
18,19 \\
0\end{array}$ & $\begin{array}{c}220,5 \\
26,99 \\
6\end{array}$ \\
\hline $\begin{array}{l}\text { LIFE } \\
\text { ASSURANC } \\
\text { E }\end{array}$ & $\begin{array}{l}20,37 \\
1,170\end{array}$ & $\begin{array}{l}21,36 \\
8,204\end{array}$ & $\begin{array}{l}24,26 \\
4,674\end{array}$ & $\begin{array}{l}24,50 \\
7,371\end{array}$ & $\begin{array}{l}28,54 \\
2,839\end{array}$ & $\begin{array}{l}27,21 \\
2,033\end{array}$ \\
\hline $\begin{array}{l}\text { MEDICAL } \\
\text { INSURANC } \\
\text { E }\end{array}$ & $\begin{array}{l}80,73 \\
1,098\end{array}$ & $\begin{array}{l}98,36 \\
1,038\end{array}$ & $\begin{array}{l}99,73 \\
0,269\end{array}$ & $\begin{array}{c}110,3 \\
40,72 \\
9 \\
\end{array}$ & $\begin{array}{c}113,3 \\
56,52 \\
5 \\
\end{array}$ & $\begin{array}{c}124,0 \\
31,38 \\
9 \\
\end{array}$ \\
\hline $\begin{array}{ll}\text { Total } & \text { Paid } \\
\text { Claims } & \end{array}$ & $\begin{array}{c}282,1 \\
04,03 \\
3\end{array}$ & $\begin{array}{c}344,9 \\
34,71 \\
4 \\
\end{array}$ & $\begin{array}{c}323,0 \\
42,20 \\
1 \\
\end{array}$ & $\begin{array}{c}317,0 \\
28,99 \\
2 \\
\end{array}$ & $\begin{array}{c}372,9 \\
17,55 \\
4 \\
\end{array}$ & $\begin{array}{c}371,7 \\
70,41 \\
8 \\
\end{array}$ \\
\hline
\end{tabular}

Source: Jordan insurance federation (JOIF)

\section{B. The role of insurance sector in economic growth}

Theoretical studies and empirical evidence revealed that countries with higher developed financial systems would be characterized by more stable and faster growth in the long-run. There is a significant positive effect for well-developed financial markets on total factor productivity, and that support the higher long-run growth (Haiss \& Sümegi, 2008).

The growth theory states that well developed financial intermediation can promote economic growth through marginal productivity of capital, efficiency of channeling savings to investment, savings rate and technological innovations (Eze and Okoye, 2013).

The insurance sector can play a significant role in financial and economic development. It can reduces the amount of capital that would be needed to cover the prospective losses through risk pooling, and thus encouraging additional investment, output, innovation, and competition (Lester, 2010).

Since the insurance sector considers as the second main type of financial sector after banks, we can conduct its importance on the productivity which reflects the economic growth in the country, it could contribute to the economic through determine potential burden of loss and spreading losses that may occur, so protect the economic from exposing to high risk.

Gabriel (2015) illustrated that the insurance industry promotes economic growth and structural development through the following channels:

1. Providing broader insurance coverage directly to firms, improving their financial soundness.

2. Fostering entrepreneurial attitudes, encouraging investment, innovation, market dynamism and competition. 
3. Offering social protection alongside the state, releasing pressure on public sector finance.

4. Enhancing financial intermediation, creating liquidity and mobilizing savings. As major institutional investors, insurers gather dispersed financial resources, and channel them towards investment opportunities, facilitating companies' access to capital.

5. Promoting sensible risk management by households and firms, contributing to sustainable and responsible development.

6. Enhancing stable consumption throughout life.

\section{MODEL SPECIFICATION}

The regression analysis has been adopted for the study with a pooled OLS (POLS) equation estimated/expressed mathematically as: $y=a+b x+\mu$ Where; $y=$ Dependent variables, $\mathrm{a}=$ Intercept or Autonomous Variable. $\mathrm{b}=$ co-efficient of the independent variable or the slope, $\mathrm{x}=$ Independent Variable, $\mu=$ Stochastic variable.

The econometric model of this functional relationship is given as:

$\mathrm{GDP}=\alpha+\beta_{1} \mathrm{ROE}+\beta_{2} \mathrm{EPS}+\beta_{3} \mathrm{NRP}+\beta_{4} \mathrm{NTR}+\mu$ (1)

Where:

GDP $=$ Gross domestic product.

$\mathrm{ROE}=$ Return on equity.

EPS $=$ Earning per share .

NRP $=$ Net Realized Premiums to Shareholders Equity.

NTR $=$ Net Technical Reserves to Net Realized Premiums. $\alpha=$ Intercept of the regression line.

$\mathrm{B}_{1,2,3,4}=$ Coefficient of insurance profitability ROA, ROE, EPS, NRP, and NTR.

$\mu=$ Error term.

\section{DATA ANALYSIS AND DISCUSSION}

\section{A. Description study variables}

The sample of the study consists of 15 insurance companies listed in Amman stock exchange; where the researchers chooses this sample depend on the required data available for the period 2007-2016.

Tables below reflect a summary of the results of descriptive statistics for the variables of the study:

Table (5): Summary results of descriptive statistics

\begin{tabular}{|c|c|c|c|c|}
\hline Variable & Mean & SD & Min & Max \\
\hline GR & 0.100711 & 0.068091 & 0.030315 & 0.285374 \\
\hline EPS & 0.058768 & 0.139631 & -0.44 & 0.62 \\
\hline NRP & 1.107276 & 0.510679 & 0.1408 & 2.6252 \\
\hline NTR & 2.806249 & 13.12644 & 0.1366 & 106.68 \\
\hline ROE & 19.08757 & 40.6525 & -124.01 & 168.92 \\
\hline SOurce & & & & \\
\hline
\end{tabular}

Source: prepared by the researchers based on the results of the statistical analysis.

\section{B. From the table above we can note the following \\ 1) Growth Rate in (GDP)}

The mean of Growth Rate in (GDP was about (10\%), and the standard deviation approximately $(7 \%)$, this growth has ranged between $(3 \%)$ as minimum and $(28.5 \%)$ as maximum approximately.

2) Earning Per Share (EPS)

The mean of earning per share was about $(6 \%)$, and the standard deviation approximately $(14 \%)$, this ratio has ranged between $(-44 \%)$ as minimum, and $(62 \%)$ as maximum.

3) Net Realized Premiums to Shareholders Equity (NRP)

The mean of net realized premiums to shareholders equity was about $(111 \%)$, and the standard deviation approximately $(51 \%)$, this ratio has ranged between $(14 \%)$ as minimum, and approximately (263\%) as maximum.

\section{4) Net Technical Reserves to Net Realized Premiums (NTR)}

The mean of net technical reserves to net realized premiums was about $(280 \%)$, and the standard deviation approximately (131\%), this ratio has ranged between $(13 \%)$ as minimum, and approximately (1066\%) as maximum.

\section{5) Return on Equity (ROE)}

The mean of return on equity was about (191\%), and the standard deviation approximately $(406 \%)$, this ratio has ranged between $(1240-\%)$ as minimum, and approximately $(1689 \%)$ as maximum.

Table (6): Summary results of correlation matrix

\begin{tabular}{|c|c|c|c|c|c|}
\hline Variable & GR & EPS & NRP & NTR & ROE \\
\hline GR & 1 & & & & \\
\hline EPS & -0.049 & 1 & & & \\
\hline NRP & $\begin{array}{c}-0.187 \\
* *\end{array}$ & $\begin{array}{c}-0.194 * \\
*\end{array}$ & 1 & & \\
\hline NTR & -0.085 & 0.120 & 0.084 & 1 & \\
\hline ROE & $\begin{array}{l}0.499 \\
* * *\end{array}$ & 0.134 & -0.127 & -0.034 & 1 \\
\hline \multicolumn{2}{|c|}{$\begin{array}{c}* * * \text { significant at } \\
1 \%\end{array}$} & \multicolumn{2}{|c|}{$\begin{array}{c}* * \text { significant at } \\
5 \%\end{array}$} & \multicolumn{2}{|c|}{$\begin{array}{c}\text { *significant at } \\
10 \%\end{array}$} \\
\hline
\end{tabular}

Source: prepared by the researchers based on the results of the statistical analysis.

the previous table shows us a positive correlation between the external debt (ED) as a dependent variable and all of the following independent variables: the budget deficit 
(DEFICIT), trade openness (OPP), trade (TOT), and the exchange rate (EXCHR), but this relationship was not statistically significant, also it was also clear to us that there is a negative relationship between the dependent variable external debt (ED) and the gross domestic product per capita (GDP. pc), and this relationship was also not statistically significant.

Table (7): Unit root test results for residual error

\begin{tabular}{|c|c|c|}
\hline variable & t- value & probability \\
\hline residual error & -13.8524 & 0.000 \\
\hline
\end{tabular}

The results of Augmented Dickey-Fuller (ADF) test show that the residual error for the model was stationary, where the probability was significant at $(1 \%)$, and this result indicated perfect model.

\section{REGRESSION RESULTS}

We used Hausman Test to choice between the Random Effect Model results and Fixed Effect Model results.

Table (8): Hausman Test

\begin{tabular}{|c|c|}
\hline chi $^{\mathbf{2}}$ & Pro. \\
\hline 3.87649 & 0.423 \\
\hline
\end{tabular}

Source: prepared by the researcher based on the results of the statistical analysis.

From the table above we note that the probability value was (0.423), and this value is insignificant at $(5 \%)$, which mean that the Random Effect Model results are more suitable than Fixed Effect Model results.

A. Regression Results Using Random Effect Model:

Table (9): Random Effect Model Results

\begin{tabular}{|c|c|c|}
\hline variable & Sig. value & Beta value \\
\hline EPS & $0.0758 *$ & -0.068385 \\
\hline NRP & $0.0592 * *$ & -0.019768 \\
\hline NTR & 0.6142 & -0.000201 \\
\hline ROE & $0.000 * * *$ & 0.000833 \\
\hline Constant value & 0.000 & 0.111278 \\
\hline R-Squared & \multicolumn{2}{|c|}{0.286072} \\
\hline Sig. for F statistic & \multicolumn{2}{|c|}{0.000} \\
\hline $\begin{array}{c}\text { Significant at } \\
1 \% * * *\end{array}$ & $\begin{array}{c}\text { Significant at } \\
5 \% * *\end{array}$ & $\begin{array}{c}\text { Significant at } \\
10 \% *\end{array}$ \\
\hline
\end{tabular}

Source: prepared by the researcher based on the results of the statistical analysis.

From the table above we note the following:

EPS: there is a significant negative impact for the earning per share on the economic growth, and this can be noted from the Sig. value which was $(0.0758)$, and this value was significant at $(10 \%)$. Thus we reject the null hypothesis and accept the first proved hypothesis of the study that says: There is a significant statistical effect for earning per share in insurance company on economic growth in Jordan.

NRP: there is a significant negative impact for the net realized premiums to shareholders equity on the economic growth, and this can be noted from the Sig. value which was $(0.0592)$, and this value was significant at $(5 \%)$. Thus we reject the null hypothesis and accept the second proved hypothesis of the study that says: There is a significant statistical effect for net realized premiums to shareholders equity in insurance company on economic growth in Jordan.

NTR: there is no significant impact for the net technical reserves to net realized premiums on the economic growth, and this can be noted from the Sig. value which was (0.6142), and this value was insignificant. Thus we accept the null hypothesis and reject the third proved hypothesis of the study that says: There is a significant statistical effect for net technical reserves to net realized premiums in insurance company on economic growth in Jordan.

ROE: there is a significant positive impact for the return on equity on the economic growth, and this can be noted from the Sig. value which was $(0.0000)$, and this value was significant at $(1 \%)$. Thus we reject the null hypothesis and accept the fourth proved hypothesis of the study that says: There is a significant statistical effect for return on equity in insurance company on economic growth in Jordan.

R-Squared: The R-Squared value was about (29\%), which means that the proportion that explained by the independent variables from the changes occurred in the dependent variable was $(29 \%)$ and there are other factors the affect the dependent variable with percent of $(71 \%)$.

We can write the equation as follow:

GDP $=0.111-0.068$ EPS $-0.020 \mathrm{NRP}-0.0002 \mathrm{NTR}+$ $0.001 \mathrm{ROE}$

\section{CONCLUSION}

In this paper the different impact of insurance company's profitability on economic growth have been examined through different measurements for the profitability unlike in most previous studies done, where taken the impact of economic growth on profitability and the determinants of the profitability. It was found that earning per share, and net realized premiums to shareholders equity have a negative impact on the economic growth, this results due to Jordanian insurance sector which consider as one of emerging market, also the period of study was during the financial crises 2008-2009, so the attitude of the customer not to invest on insurance company, and this make the premium at opposite effect with the economic growth. On the other hand the results revealed that technical reserves to net realized premiums doesn't contribute to the economic growth, which means that the Jordanian 
insurance companies don't relies on this reserve in investment.

Finally, a significant positive impact for the return on equity on the economic growth had been shown, where the return on equity considered as the most common measurement of profitability for different industries, and through this tool the profitability doesn't depend on the realized premiums, so it contributes to the economic growth in positive manner.

According to the results, the study recommended to encourage individuals and investors to participate in insurance in various fields, it's very important to spread awareness among members of the community about the importance of the insurance, also, Jordanian insurance companies must exploit the reserves and realized premiums in different investment which enhance the economic growth. Finally, farther research must conduct to find the impact of insurance company's profitability on economic growth but through different profitability's variables and different period, besides adding financial and economic control variables.

\section{REFERENCES}

[1] Adekola, O. (2016). The Effect of Banks Profitability on Economic Growth in Nigeria. Journal of Business and Management, 18 (3), 1-9.

[2] Alomari, M., and Azzam, I. (2017). Effect of the Micro and Macro Factors on the Performance of the Listed Jordanian Insurance Companies. International Journal of Business and Social Science, 8 (2), 66-73.

[3] Berhe, T., \& Kaur, P. (2017). Determinants of insurance companies' profitability Analysis of insurance sector in Ethiopia. International Journal of Research in Finance and Marketing (IJRFM), 7 (4), 124-137.

[4] Datu, N., (2016). How do insurer specific indicators and macroeconomic factors affect the profitability of insurance business? A panel data analysis on the Philippine Non-life Insurance market. Presented at the DLSU Research Congress, De La Salle University, Manila, Philippines, 4, 1-7.

[5] Eliskovska, T. (2015). Microeconomic and macroeconomic determinants of the profitability of the insurance sector in Macedonia. Economics and Business Review, 1 (15), No. 3, 38-57.

[6] Eze, O. R. \& Okoye, V. (2013). Analysis of insurance practices and economic growth in Nigeria: using co-integration test and error correction model, Global Advanced Research Journal of Management and Business Studies, 2(1), 063-070.

[7] Gabriel , M. (2015). Impact of Insurance Sector Development on the Growth of Nigeria Economy. International Journal of Advanced Academic Research, 1 (2), 1-21.

[8] Haiss, P., \& Sümegi, K. (2008). The Relationship of Insurance and Economic Growth - A Theoretical and Empirical Analysis, EcoMod Conference, Hongkong, 1-38.

[9] Jeng, V., \& Yang, S. (2014). A New Look at the Dynamic Interrelationship between Growth and Profitability in the Chinese Property Liability Insurance Industry. Academia Economic Papers, 42 (3), 369-401.

[10] Lee, C. (2014). The Effects of Firm Specific Factors and Macroeconomic on Profitability of Property- Liability Insurance Industry in Taiwan. Asian Economic and Financial Review, 4(5), 681-691.

[11] Lester, R. (2010). The Insurance Sector in the Middle East and North Africa: Challenges and Development Agenda. the World Bank, the Middle East Insurance Review, 1-42.

[12] Lire, A., \& Tegegn, T. (2016). Determinants of Profitability in Private Insurance Companies in Ethiopia. Journal of Poverty, Investment and Development, 26, 85- 92.

[13] Mehari, D., \& Aemiro, T. (2013). Firm Specific Factors that Determine Insurance Companies' Performance in Ethiopia. European Scientific Journal, 9(10), 245-255.

[14] Naveed, A., Zulfqar, A., \& Ahmad, U. (2011). Determinants of Performance: A Case of Life Insurance Sector of Pakistan. International Research Journal of Finance and Economics, Eurojournals Publishing, Inc.
[15] Njegomir, V., \& Stojić, D. (2010). Does Insurance Promote Economic Growth: The Evidence From EX-Yugoslavia Region. EKON. MISAO I PRAKSA DBK. GOD XIX. BR. 1., 31-48.

[16] Ortyński, K. (2016). Determinants of Profitability of General Insurance Companies Performance in Poland. Central European Review of Economics \& Finance, 12 (2), 53-66.

[17] Sambasivam, Y., \& Ayele, A. (2013). A Study on the Performance of Insurance Companies in Ethiopia. International Journal of Marketing, Financial Services \& Management Research, 2 (7), 138- 150.

\section{Authors Profile}

Dr.*Siti Nurain Muhmad, PhD Bachelor of Accounting Programme, School of Maritime Business and Management, University Malaysia Terengganu, 21030 Kuala Nerus, Terengganu, Malaysia. Email: sitinurain@umt.edu.my

Wesam Salameh Alzboon, $\mathrm{PhD}$ Student, University Malaysia Terengganu, Terengganu, Malaysia. Email: wesamezboon@ hotmail.com.

Fatima Alhamshary, Lecturer, Administration \& Financial Sciences Department, Community Collage of Qatif, Imam Abdulrahman Bin Faisal University, P.O. Box 36675, Dammam, Saudi Arabia. Email: falhamshary@iau.edu.sa. 